\begin{tabular}{|l|l|l|l|l|l|}
\hline J. Tek. Ling & Vol.10 & No.3 & Hal. 271 - 276 & Jakarta, Sept 2009 & ISSN 1441-318X \\
\hline
\end{tabular}

\title{
IDENTIFIKASI SENYAWA KIMIA DAN AKTIVITAS ANTIBAKTERI EKSTRAK Piper Sp. ASAL PAPUA
}

\author{
Sumarnie-H.Priyono, dan Praptiwi \\ Peneliti Bidang Botani, Puslit Biologi-LIPI \\ Cibinong Science Center, JI Raya Bogor-Jakarta Km 46, Cibinong, Bogor
}

\begin{abstract}
The aim of this study was to identity the chemical compounds of the piper sp. Fruit originated from Papua, that has been used as "sirih pinang"(chew betle) and to determine the antibacterial activity of hexane and chloroform extraxt of piper sp. to Gram + bacteria isolates(Bacillus subtilis, Listeria monocytogenes dan Staphylococcus aureus) and Gram - bacteria isolates(Salmonella typhimurium, Eschericia coli and Pseudomonas pseudomallei). The extract concentration were $50 \%$ and $25 \%$, and every treatment consisted of 3 replications. The bacteriae growth media was Mueller Hinton Agar(MHA). The result of phytochemical screening of Piper sp.fruit(ether, alcohol,and water extracts)showed that it contained esential oil, lipid,emodol,tannin, reducing sugar, anthrasenoid,polyuronide, glucocide, steroid glycoside.
\end{abstract}

Key words: Piper sp., phytochemical screening and in-vitro antibacterial test.

\section{PENDAHULUAN}

\subsection{Latar belakang}

Sirih (Piper betle) merupakan salah satu jenis tumbuhan dari famili Piperaceae yang telah dikenal luas sehingga mempunyai beberapa nama daerah, diantaranya : sireh, suruh $(\text { Jawa })^{1}$. Pemanfaatan sirih yang paling umum adalah sebagai bahan untuk sirih pinang. Bagian tumbuhan sirih untuk bahan sirih pinang adalah daun (umumnya di Indonesia bagian barat) dan buah (umumnya di Indonesia bagian timur). Penggunaan buah untuk acara penyambutan tamu baik diacara resmi atau kekeluargaan dari rumah kerumah. Bahkan hampir tiap-tiap orang asli bukan pendatang masing-masing membawa atau mempersiapkan sirih pinang dalam sebuah kantong untuk keperluan

bersilahturahmi antar teman maupun saudara baik pria maupun wanita. Budaya sirih pinang ini juga dijumpai di

NTT maupun di Maluku. Pasti adamanfaat ilmiah yang perlu dicari kebenaran faktanya dan bukan sekedar budaya atau kearifan lokal. Tumbuhan dari Genus Piper, seperti Piper nigrum, P. methysticum, P. auritum dan $P$. betle telah dikenal sejak lama sebagai komoditi pertanian untuk rempah, isektisida pada lahan pertanian dan bahan obat-obatan dengan nilai ekonomi yang tinggi. ${ }^{2)}$ Beberapa penelitian melaporkan bahwa jamu tradisional yang menggunakan serbuk daun sirih/ Piper betle dan cabe jawa /Piper retrofractum sebagai salah 
satu penyusunnya mempunyai tingkat kontaminasi bakteri yang sangat rendah. Hal ini disebabkan karena adanya sifat antibakteri dan anti jamur dari daun sirih dan buah cabe jawa. Telah dilaporkan bahwa minyak atsiri yang terkandung dalam daun sirih dan buah cabe jawa berperan dalam aktivitas sebagai antibakteri dan antiseptic. Aktivitas tersebut disebabkan adanya kandungan senyawa fenolik bermolekul rendah ${ }^{3)}$.

Secara tradisional, tumbuhan genus Piper memperlihatkan khasiat dan kegunaan yang unik dan menarik. Buah P. longum biasa digunakan untuk mengobati kejang usus ${ }^{4}$. Tumbuhan wati atau P. methysticum dapat memberikan efek narkotik dan bersifat sedatif yang merupakan tradisi adat pada beberapa suku di Propinsi Papua ${ }^{5}$. Piper aduncum, secara tradisional dimanfaatkan sebagai obat sakit perut, kencing nanah dan penolak serangga. Secara in-vitro, ekstrak kasar petroleum eter dari P. aduncum telah dibuktikan mempunyai aktivitas yang kuat sebagai molusisida melawan Biomphalaria glabrata. Ekstrak ini juga memperlihatkan aktivitas yang signifikan sebagai antibakteri melawan Bacillus subtilis, Micricoccus luteus dan Escherichia coli ${ }^{6}$ ). Ekstrak etanol dan senyawa murni piperina dari P. longum mampu mengobati $90 \%$ dan $40 \%$ berturutturut tikus yang terjangkit caesal amoebiasis 7).

Sejauh ini, baru sekitar 112 jenis tumbuhan (sekitar 10\%) dari Genus Piper yang telah diinvestigasi komponen kimianya yang meliputi 667 senyawa kimia yang berbeda yang terdiri dari 190 alkaloid, 49 lignan, 70 neolignan, 97 terpena, 15 steroid, 18 kavapirona, 17 calkon, 16 flavona, 6 flavanona, 4 piperolida dan 146 golongan senyawa lainnya ${ }^{8)}$. Umumnya bagian tumbuhan yang digunakan untuk pengobatan adalah daun atau buah.Daun sirih telah dimanfaatkan dalam berbagai ramuan obat tradisional ${ }^{4}$. Daunnya juga telah dilaporkan mempunyai sifat antitumor 9) . Heyne (1987) menyatakan bahwa ekstrak daun sirih digunakan untuk berkumur, membersihkan pernafasan, menghentikan pendarahan pada gigi yang dicabut ${ }^{2)}$. Rebusan daun sirih yang ditambah gula dapat dimanfaatkan sebagai obat batuk. Daunnya dapat digunakan sebagai obat batuk, obat cacing, dan antiseptik pada luka. Daun yang dipanaskan kemudian ditempelkan di dada untuk mengobati batuk dan asma ${ }^{9) .}$

Daun Piper betle mengandung minyak atsiri 0.1-1.8\%. Senyawa kimia yang terdapat pada minyak atsiri Piper betle adalah fenol (eugenol, chavicol, estragol) dan chavibeto/(9), alkaloid arakene, terpen dan seskuiterpen ${ }^{10)}$. Selanjutnya Dyer, Richards dan Dodson(2004) menyatakan bahwa daun muda mempunyai kadar minyak atsiri lebih tinggi dari daun tua ${ }^{8)}$. Chavicol sebagai komponen kimia utama pada minyak atsiri sirih bertanggung jawab terhadap bau khas pada sirih dan bersifat antibakteri kuat yaitu 5 kali dari fenol ${ }^{2}$. Ekstrak daun dan minyak atsiri mempunyai aktivitas sebagai antibakteri dan antifungi. Minyak atriri mempunyai sifat sebagai antelminthic (obat cacing) ${ }^{1}$. Menurut Agusta (2000) bahwa komposisi minyak atsiri daun (kering angin) Piper aduncum L. Mengandung sekitar $1 \%$ minyak atsiri dengan komposisi: 20 macam senyawa, Piper amboinensis (Miq) D.C. komposisi minyak atsiri bagian atas tumbuhan (kering angin) mengandung sekitar $0.6 \%$ minyak atsiri dengan komposisi: 9 macam senyawa. Sedangkan Piper methysticum Forst. komposisi minyak atsiri bagian atas tumbuhan (kering angin) mengandung sekitar $0.7 \%$ minyak atsiri dengan komposisi: 14 macam senyawa ${ }^{5)}$.

\subsection{Tujuan}

Pada penelitian ini dilakukan penapisan fitokimia untuk melakukan identifikasi komponen kimia yang terdapat pada buah Piper sp. yang dimanfaatkan sebagai bahan sirih pinang di Papua. Selain itu juga dilakukan uji antibakteri secara invitro untuk mengetahui aktivitas antibakteri dari ekstrak buah Piper sp. asal Papua. 


\section{METODOLOGI}

\subsection{Tempat dan Waktu Penelitian}

Penelitian dilakukan di laboratorium fitokimia Treub Bidang Botani, Puslit. Biologi LIPI, dan uji antibakteri di laboratorium bakteriologi umum Balai Besar Penelitian Veteriner Bogor (B. Balitvet, Bogor).

Bahan :

Buah Piper sp. diperoleh dari Jayapura (Papua). Buah dibersihkan dari kotoran kemudian dipotong dan dikeringkan. Buah yang telah kering digiling dan diayak. Serbuk yang diperoleh digunakan untuk bahan penapisan fitokimia, dan uji antibakteri secara in-vitro.

\section{Penapisan Fitokimia : ${ }^{11)}$}

Serbuk daun ditimbang sebanyak 25 gram kemudian dimaserasi dengan eter. Filtrat yang ada ditampung, kemudian ditambahkan pelarut lagi sampai filtrat yang ada tidak berwarna. Filtrat dipekatkan menjadi $50 \mathrm{ml}$. Ekstrak eter yang diperoleh diuji untuk kandungan minyak atisiri, lemak dan asam lemak jenuh, sterol dan triterpenoida, alkaloida basa, aglikon flavonoida dan emodol. Residu yang ada dikeringkan kemudian dimaserasi dengan alkohol. Filtrat yang ada ditampung sampai tidak berwarna. Filtrat dipekatkan kemudian ekstrak yang diperoleh diuji terhadap tannin, gila pereduksi, garam alakaloida, antrasenoida, glukosida steroid dan flavonoid. Hal yang sama selanjutnya menggunakan pelarut air. Ekstrak air yang diperoleh diuji terhadap poliuronida, gula pereduksi, glukosida, saponin, tannin, garam alkaloida, antrasenoida, glukosida steroid dan flavonoid.

\section{Ekstraksi :}

Serbuk/simplisia dimasukkan dalam corong maserasi kemudian direndam dengan methanol $80 \%$ selama 24 jam. Filtrat yang ada ditampung kemudian dipekatkan dengan rotary evaporator. Hal ini dilakukan sampai filtrat yang ada tidak berwarna. Ekstrak pekat yang diperoleh selanjutnya dipartisi berturut-turut dengan pelarut heksana, khloroform dan etil asetat dengan menggunakan corong pisah. Bagian yang terlarut pada pelarut heksana, khloroform dan etil asetat dipekatkan dengan rotary evaporator sehingga diperoleh ekstrak heksana, khloroform dan etil asetat untuk bahan uji antibakteri.

\section{Uji Antibakteri :}

Ekstrak heksana dan khloroform yang diperoleh diuji antibakterinya secara in-vitro terhadap beberapa isolat bakteri Gram Negatif maupun Gram Positif. Konsentrasi ekstrak yang diuji adalah 50 dan 25\%. Tiap-tiap konsentrasi mempunyai 3 ulangan. Selanjutnya $15 \mu \mathrm{l}$ ekstrak diteteskan pada kertas cakram steril dan diletakkan pada media Mueller Hinton Agar (MHA) yang telah diinokulasi dengan isolat bakteri uji. Isolat bakteri yang diuji adalah bakteri Gram Positif (Bacillus subtilis, Listeria monocytogenes dan Staphylococcus aureus) dan Gram Negatif (Salmonella typhimurium, Eschericia coli dan Pseudomonas pseudomallei). Media yang telah diinokulasi tersebut selanjutnya diinkubasi pada suhu $37^{\circ} \mathrm{C}$ selama 24 jam ${ }^{12)}$. Sifat antibakteri ditunjukkan dengan adanya daerah bening di sekitar kertas cakram yang menunjukkan adanya penghambatan pertumbuhan.

\section{HASIL DAN PEMBAHASAN}

\subsection{Hasil Penapisan kimia}

Penapisan fitokimia suatu tumbuhan dilakukan untuk mengetahui senyawasenyawa kimia yang terdapat pada tumbuhan tersebut. Penapisan dilakukan dengan menggunakan ekstrak eter, ekstrak alkohol dan ekstrak air. Pelarut untuk ekstraksi mempunyai kepolaran yang berbeda. Hal ini disebabkan kandungan kimia dari suatu tumbuhan hanya dapat terlarut pada pelarut yang sama kepolarannya, sehingga suatu golongan senyawa dapat dipisahkan dari senyawa lainnya ${ }^{13)}$. Hasil penapisan fitokimia buah Piper sp. yang diperoleh dari Papua terdapat pada Tabel 1. 
Tabel 1. Kandungan kimia ekstrak eter, alkohol dan air buah Piper sp.

\begin{tabular}{|l|l|c|c|c|}
\hline No & Jenis senyawa kimia & Ekstrak Eter & Ekstrak alkohol & Ekstrak air \\
\hline 1 & Minyak atsiri & ++ & $\mathrm{v}$ & $\mathrm{v}$ \\
\hline 2 & Lemak \& asam lemak & + & $\mathrm{v}$ & $\mathrm{v}$ \\
\hline 3 & Steroid \& triterpenoid & - & $\mathrm{v}$ & $\mathrm{v}$ \\
\hline 4 & Alkaloid basa & - & $\mathrm{v}$ & $\mathrm{v}$ \\
\hline 5 & Aglikon flavon & - & $\mathrm{v}$ & $\mathrm{v}$ \\
\hline 6 & Emodol & + & $\mathrm{v}$ & $\mathrm{v}$ \\
\hline 7 & Tanin & $\mathrm{v}$ & + & + \\
\hline 8 & Gula pereduksi & $\mathrm{v}$ & + & + \\
\hline 9 & Garam alkaloid & $\mathrm{v}$ & - & - \\
\hline 10 & Antrasenoid & $\mathrm{v}$ & + & $\mathrm{v}$ \\
\hline 11 & Glikosida steroid & $\mathrm{v}$ & - & + \\
\hline 12 & Flavonoid & $\mathrm{v}$ & - & - \\
\hline 13 & Poliuronida & $\mathrm{v}$ & $\mathrm{v}$ & + \\
\hline 14 & Glukosida & $\mathrm{v}$ & $\mathrm{v}$ & + \\
\hline 15 & Saponin & $\mathrm{v}$ & $\mathrm{v}$ & - \\
\hline
\end{tabular}

Keterangan : + : ada, - : tidak ada, v : tidak diuji

\subsection{Hasil uji antibakteri}

Berdasarkan hasil pada Tabel 1. diketahui bahwa buah Piper $s p$. asal Papua mengandung minyak atsiri, lemak dan asam lemak, emodol, tanin, gula pereduksi, antrasenoid, poiluronida, glukosida dan glikosida steroid. Minyak atsiri Piper betle telah diketahui bersifat bioaktif yaitu mempunyai aktivitas antelmintic terhadap cacing pita. Tyler, Brady dan Robbers(1988) menyatakan bahwa tanin dapat digunakan untuk mengatasi hemoroid sedang antrasenoid yang bersifat pencahar digunakan untuk mengatasi masalah konstipasi ${ }^{14)}$. Saponin , tannin dan flavonoid merupakan zat antibakteri yang berasal dari tumbuh-tumbuhan ${ }^{15,16)}$. Oleh karena itu pemilihan Staphyloccocus aureus, Listeria monocytogenes sebagai bakteri Gram positif dan Pseudomonas pseudomallei, Salmonella typhimurium dan Escherichia coli, sebagai bakteri Gram negative diharapkan pertumbuhannya dapat dihambat oleh fraksi heksana buah Piper sp. karena mengandung zat antibakteri, sehingga hasil penelitian yang dilakukan lengkap.

Tabel 2. Rataan zona hambat ekstrak heksan dan khloroform buah Piper sp.

\begin{tabular}{|c|c|c|c|c|c|c|c|}
\hline No & $\begin{array}{l}\text { Jenis ekstrak / } \\
\text { konsentrasi (\%) }\end{array}$ & 1 & 2 & 3 & 4 & 5 & 6 \\
\hline 1 & Heksana / 50 & 19.33 & 28.00 & 24.33 & 29.00 & 21.00 & 25.33 \\
\hline 2 & Heksana / 25 & 18.67 & 28.33 & 21.67 & 27.33 & 21.00 & 19.00 \\
\hline 3 & Khloroform / 50 & 25.00 & 31.67 & 27.33 & 35.00 & 27.67 & 23.67 \\
\hline 4 & Khloroform / 25 & 21.67 & 29.33 & 25.33 & 32.00 & 24.33 & 20.00 \\
\hline \multicolumn{5}{|c|}{$\begin{aligned} \text { Keterangan : Isolat } 1: \text { Bacillus subtilis } \\
\text { Isolat } 2: \text { Listeria monocytogenes } \\
\text { Isolat } 3: \text { Staphilococcus aureus }\end{aligned}$} & \multicolumn{3}{|c|}{$\begin{array}{l}\text { Isolat } 4 \text { : Pseudomonas pseudomalle } \\
\text { Isolat } 5 \text { : Salmonella typhimurium } \\
\text { Isolat } 6 \text { : Eschericia coli }\end{array}$} \\
\hline
\end{tabular}


Hasil pada Tabel 2. menunjukkan bahwa ekstrak heksana dan khloroform pada konsentrasi $50 \%$ dan $25 \%$. dapat menghambat pertumbuhan isolat bakteri Gram Positif (Bacillus subtilis, Listeria monocytogenes dan Staphylococcus aureus) dan Gram Negatif (Salmonella typhimurium, Eschericia coli dan Pseudomonas pseudomallei) yang diuji. Hasil tersebut menunjukkan bahwa penghambatan pertumbuhan bakteri oleh ekstrak heksana dan khloroform pada konsentrasi $25 \%$ termasuk mempunyai aktivitas yang kuat karena diameter penghambatannya lebih dari $10 \mathrm{~mm}$. Hasil tersebut juga menunjukkan bahwa meningkatnya konsentrasi ekstrak juga meningkatkan diameter daerah hambat pertumbuhan. Hal ini disebabkan oleh meningkatnya konsentrasi senyawasenyawa kimia yang bersifat antibakteri pada sirih dengan meningkatnya konsentrasi ekstrak.

\section{KESIMPULAN \& SARAN}

* Buah Piper sp. asal Papua mengandung minyak atsiri, lemak dan asam lemak, emodol, tanin, gula pereduksi, antrasenoid, poiluronida, glukosida dan glikosida steroid

* Ekstrak heksan dan khloroform pada konsentrasi $25 \%$ mempunyai aktivitas antibakteri terhadap 6 isolat bakteri yang diuji yaitu isolat bakteri Gram Positif (Bacillus subtilis, Listeria monocytogenes dan Staphylococcus aureus) dan Gram Negatif (Salmonella typhimurium, Eschericia coli dan Pseudomonas pseudomallei).

* Perlu dilakukan uji antibakteri selanjutnya sehingga diketahui konsentrasi penghambatan minimum dari ekstrak Piper sp. asal Papua.

\section{UCAPAN TERIMAKASIH}

Kepada Ibu Mindarti Harapini (Puslit. Biologi LIPI CSC) dan Bapak Tono(B. Balitvet,Bogor) yang telah banyak membantu dalam penyelesaian penelitian ini diucapkan terimakasih atas dukungannya.

\section{DAFTAR PUSTAKA}

1. Burkill, I.H., 1935. A Dictionary of the Economic Products of the Malay Peninsula. Crown Agents for the Colonies. Millbank, London.

2. Heyne, K., 1987. Tumbuhan Berguna Indonesia. Diterjemahkan oleh : Badan Litbang Kehutanan. Jakarta.

3. Rachmat, M., Hartati, M.S., dan Wahyono,S., 2000. Aktivitas Antibakteri dan Sediaan Obat Kumur Beriisi Minyak Atsiri daun Sirih (Piper betle Linn.) dan Analisis komposisi Minyak Atsirinya. Majalah Farmasi Indonesia Vol.II,N0.4,2000, 235-240.

4. Perry, LM., and Metzger, J., 1980. Medicinal Plants of East and SouthEast Asia. Attributed Properties and Uses. The MIT Press. London.

5. Agusta A., 2000. Minyak Atsiri Tumbuhan Tropika Indonesia. Penerbit ITB Bandung. 83-87.

6. Orjala, J., Erdelmeier. CAJ., Wright, AD., Rali, T., and Sticher, O., 1993. Five new prenylated-hydroxybenzoic acid derivatives with antimicrobial and moluscicidal activity from Piper aduncum leaves. Planta Med., 59(6), 546-551.

7. Ghosal, S., Prasad, BN., and Lakshmi. 1996. Antiamoebic Activity of Piper longum Fruits Against Entamoeba histolytica in vitro and in vivo. J. Ethnopharmacol 50(3), 167-70. 
8. Dyer, L., Richards, J., and Dodson, C., 2004. Isolation, synthesis, and evolutionary ecology of Piper Amides. In Piper: A Model Genus for Studies of Phytochemistry, Ecology, and Evolution. Lee A. Dyer and Aparna D. N. Palmer (eds). Kluwer Academic/ Plenum Publishers, 117-139

9. Quisumbing, E., 1951. Medicinal Plants of the Philippines. Dept. of Agric and Natural Resources. Manila

10. Teo, SP., and Banka, RA., 2000. Piper betle L. In : Plant Resources of SouthEast Asia 16.

Stimulants. Ed : HAM van der Vossen and $\mathrm{M}$. Wessel. Backhuys Publishers Leiden, the Netherlands

11. Cuilei, J., 1984. Methodology for Analysis of Vegetables and Drugs. Fac. of Pharmacy. Bucharest, Rumania.
12. Simmons, CG., and Craver, J., 1980. Antibiotic actinity test using the disk method. Australian Beaureau Animal Health. Brisbane.

13. Kochhar, SP., and Russel, JB., 1990. Detection, Estimation and Evaluation of Antioxidants in Food System. In :Food Antioxidant. Elsevier Applied Science. London.

14. Tyler, VE., Brady, LR., and Robbers, JE., 1988. Pharmacognosy $9^{\text {th }}$ ed. Lea \& Febiger. Philadelphia.

15. Ramstad, E.,1959. Modern Pharmacognocy. Blakiston Division, Mc Graw Hill Book Co., Inc.,London,105,213 -215. Australian Beaureau Animal Health. Brisbane.

16. Wolf, F.A., and Wolf, F.T.,1969. The Fungi, Vol.II, Hafner Publishing Company, New York, London, 372 -373 